\title{
Duane Elgin's Concept of the Living Universe from the Perspective of Neo-Romanticization
}

\author{
Andrzej Kasperek \\ University of Silesia in Katowice \\ andrzej.kasperek@us.edu.pl
}

\begin{abstract}
The article is aimed at analysing Duane Elgin's concept of the living universe from the standpoint of neo-Romanticization. The analysis is based on an understanding of Romanticism as an epoch of reinterpretation of the Western esoteric tradition. The author notices in Elgin's works the presence of ideas that were popularized in the Romantic period, thus emphasizing the motif of esoteric inspirations in his oeuvre. By turning against the idea of a non-living universe, understood as a mechanism, Elgin continues the esoteric tradition, the major ideas of which are organicism, holism and evolutionism. His works (and activity) discussed in this study are treated as factors of social change.
\end{abstract}

Keywords: Duane Elgin, living universe, occulture, neo-Romanticization, voluntary simplicity movement

Słowa kluczowe: Duane Elgin, żywy wszechświat, okultura, neoromantyzacja, ruch dobrowolnej prostoty

Duane Elgin is an important figure in the voluntary simplicity movement. As well as being a research subject for scholars from various disciplines exploring modern society and culture (sociologists, historians of idea, economists, culture experts and philosophers), Elgin has also been the spiritus movens for the movement of contesting the imperative of unconstrained consumption, which is the keystone in the development of contemporary societies. However, the promotion of the idea of a simple and more friendly environment - an ideal which constitutes an alternative to the consumer society - is, in Elgin's explorations, deeply embedded in a certain way of understanding the universe. In his works, particularly in The Living Universe, Elgin builds a concept of the living universe, permeated with awareness and spirituality. In turning against the idea of the dead universe, understood as a mechanism, Elgin 
continues the esoteric tradition, in which the key ideas are organicism, holism, and evolutionism.

However, my intention is not to focus only on the reconstruction of esoteric motifs in the works of the author of Voluntary Simplicity. His body of work and its influence will be treated here rather as an illustration of certain sociocultural processes, the common theme of which is "the massive subjective turn of modern culture," along with its Romantic roots. In other words, my aim is to view Duane Elgin's works in the mirror of broader sociocultural processes, a common feature of which is another surge in a phenomenon that can be roughly defined as the neo-Romanticization of the contemporary world, or its re-enchantment. This article is of a sociological nature (though with the noticeable presence of some motifs concerning the history of esoteric ideas) - therefore, special attention will be paid to the relations between social change and the dissemination of what is underground, "socially invisible," and pushed to the cultural margins.

Edward A. Tiryakian, no doubt one of the pioneers of sociological interest in esotericism, treats it as a factor of cultural change (cultural and social innovation). ${ }^{2}$ Discussing the revival of occultism ${ }^{3}$ in the 1960s and 1970s and promoting the sociology of occultism, Tiryakian did not treat the esoteric tradition as an atavistic element of premodern mentality. From the perspective of research into esotericism, its popularization (for example, during the final period of Rome, the Renaissance, the Reformation, fin de siècle or the times of youth counterculture) may be treated as an acid test of cultural revolution. From this standpoint, the esoteric tradition does not have to be treated as an alternative to modernity - quite the contrary, it may be defined as an important mainstay of contemporary society. Tiryakian even writes that the Renaissance, by drawing on esoteric motifs, contributed to the acceptance of the category of change and novelty. ${ }^{4}$ What was important for sociological studies on esotericism was that the sociology of the occult would become a part of the sociology of culture. ${ }^{5}$ It seems of crucial significance to place the discussion on Duane Elgin's works in the context of another concept that is important in reflections upon the relations between modern culture and esotericism - occulture. This combination of two notions ("occultism" and "culture") seems to best describe the important (for contemporary society) distribution processes of the esoteric tradition through the most modern channels of transmission which contemporary culture can offer.

${ }^{1}$ C. Taylor, The Ethics of Authenticity, Cambridge, MA 1991, p. 26 (C. Taylor, Etyka autentyczności, trans. A. Pawelec, Kraków-Warszawa 1996, p. 28).

${ }^{2}$ E.A. Tiryakian, Toward the Sociology of Esoteric Culture [in:] On the Margin of the Visible. Sociology, the Esoteric, and the Occult, E.A. Tiryakian (ed.), New York-London-Sydney-Toronto 1974, p. 273.

3 Tiryakian uses the terms "esotericism" and "occultism" rather freely here; however, he is the originator of the popular distinction according to which the term "occult" refers to practices and techniques, whereas the term "esoteric" refers to the religious-philosophical system of beliefs that is the basis for occult techniques and practices (E.A. Tiryakian, op. cit., p. 265).

${ }^{4}$ Ibidem, pp. 268-269.

${ }^{5}$ Ibidem, p. 263. 
Occulture was systematically studied by Christopher Partridge in two volumes of the work The Re-Enchantment of the West. ${ }^{6}$ The term itself is de facto a kind of oxymoron, combining what is hidden, invisible, "illegal," in the sense of the counterculture (which is opposed to the cultural mainstream), with what is common and daily. As Partridge emphasizes, the notion of occulture as a sociological concept constitutes a reservoir of ideas, beliefs, practices, symbols, and values which permeate the process of thinking, symbolizing and experiencing. ${ }^{7}$ What enhance the dissemination of esotericism, as Partridge notes, are post-materialistic values, which highlight the significance of self-expression, subjectivization and experiencing. ${ }^{8}$ The birth of the concept of occulture is largely associated with the academic work of Colin Campbell, a British sociologist and the originator of the term cultic milieu, which has turned out to be very important in the history of sociological (though not only sociological) reflection upon religion. According to Campbell, the cultic milieu constitutes the cultural underground of society and comprises all deviant (from the dominating cultural order) systems of beliefs and practices. ${ }^{9}$ This cultural underground exists apart from the mainstream of culture and encompasses heterodox religious currents, alternative spirituality, and alternative medicine and science, as well as what is related to the Western esoteric tradition - magic, mysticism, (neo)gnosis, New Age, and holistic spirituality. Arguing about the concept of cultic milieu, Partridge claims that the term "occultic" more precisely describes modern alternative religious environments than "cultic." However, it is important to note that Partridge applies a very broad meaning to the term "occultic," which encompasses what Campbell understood as the cultural underground, but - at the same time - the deviant (countercultural) nature of the ideas situated within occulture has been blunted. As an analogy to the term "popular culture," Partridge uses the term "popular occulture." Thus, what turns out to be the key to understanding what Tiryakian called "occult revival" is the phenomenon of popular culture transmitted by mass media. By permeating into the cultural mainstream and preserving its underground roots, the (Western and Eastern) esoteric tradition ceases to be countercultural and deviant in the full sense of these words. ${ }^{10} \mathrm{As}$ Partridge states, it becomes ordinary.

${ }^{6}$ See: C. Partridge, The Re-Enchantment of the West: Alternative Spiritualities, Sacralization, Popular Culture, and Occulture, vol. 1, London-New York 2004; C. Partridge, The Re-Enchantment of the West. Alternative Spiritualities, Sacralization, Popular Culture, and Occulture, vol. 2, London-New York 2005.

${ }^{7}$ C. Partridge, The Re-Enchantment of the West..., vol. 1, op. cit., p. 187.

${ }^{8}$ Idem, Occulture is Ordinary [in:] Contemporary Esotericism, E. Asprem, K. Granholm (eds.), Lancaster-Bristol 2013, p. 115.

${ }^{9}$ C. Campbell, The Cult, the Cultic Milieu and Secularization, "A Sociological Yearbook of Religion in Britain" 1972, no. 5, p. 122.

${ }_{10}$ The issue of the dissemination of what is underground in modern societies was my research interest in the book Wolność spod znaku undergroundu. Duchowość (po)nowoczesna w perspektywie hermeneutyki kultury i socjologii religii, Kraków 2012. An interesting study on the phenomenon of the increased popularization (and at the same time trivialization) of rejected knowledge, knowledge stigmatized by pop culture, was presented by Michael Barkun (see: M. Barkun, A Culture of Conspiracy: Apocalyptic Visions in Contemporary America, Berkeley 2003). 
Colin Campbell's academic output contains another point of reference used in the field of occulture. This is his proposal, put forward 25 years later than the concept of cultic milieu, to describe contemporary Western culture in terms of its Orientalization (Easternization of the West). ${ }^{11}$ Campbell goes against the current of the dominant approaches to the relation between the Westernization of the world (its synonyms here are globalization or Americanization) and the Orientalization of the West. As he writes, it is quite ignored that, while the non-Western world is adopting Western values and institutions, something entirely opposite is taking place in the West itself. ${ }^{12}$ What is very popular here (in the West) is Eastern martial arts, feng-shui, alternative medicine, yoga, massage, and Eastern religions: Buddhism and Hinduism. As Campbell notes, it is quite likely that while the rest of the world is imitating the West, the West is abandoning its roots, being fascinated with otherness.

The core of Partridge's polemics with Campbell's thesis on the Orientalization of the West is the belief of the former that what is being dealt with here is rather the neo-Romanticization of the contemporary West, and that the turn towards the East should be treated as part of this broader phenomenon (neo-Romanticization), which might be understood in terms of occulture. ${ }^{13}$ It was during the Romantic era that the culture of the Orient was discovered in the West on such a large scale for the first time. The first translations of Oriental texts and studies on the Orient appeared then as well. However, Partridge draws attention to the fact that Romantics (e.g. Herder or Hegel) treated the culture of the Orient as "inspiring articulations of their own ideas," 14 and not as a reservoir of original ideas which might radically change the notional systems of the Western world. Put simply, Romantics discovered something in the Orient which had already been present in the West. In Partridge's opinion, the activities of the Theosophical Society were associated with a more visible turn to the Orient. However, the ideas developed by the Association, especially evolutionism, also had an entirely Western character. The consecutive waves of Romantic inspirations (modernism or the youth counterculture of the 1960s and 1970s) associated with a fascination with the Orient did not change one thing: in spite of importing ideas of differentiae specificae into the West, what has remained is the activism, affirmation and ideology of progress. Resignation and fatalism are rarely written into alternative Western worldviews. ${ }^{15}$

${ }^{11}$ As far as I know, Campbell presented his concept of the Orientalization of the West for the first time in his work from 1998 (see: C. Campbell, The Easternization of the West: Reflections on a New Theodicy for a New Millennium [in:] The Ethics of the Future, E.R. Laretta (ed.), Geneva 1998, pp. 286312). Partridge argues with Campbell's theses, presented in Campbell's study published a year later: The Easternization of the West [in:] New Religious Movements: Challenge and Response, B. Wilson, J. Cresswell (eds.), London 1999, pp. 35-48. In my article, references will be made to Campbell's book The Easternization of the West: A Thematic Account of Cultural Change in the Modern Era, Boulder-London 2007. The term "Easternization" will be treated as equivalent to "Orientalization."

${ }^{12}$ C. Campbell, The Easternization of the West: A Thematic Account of Cultural Change in the Modern Era, op. cit., p. 19.

${ }_{13}$ C. Partridge, The Re-Enchantment of the West..., vol. 1, op. cit., p. 89.

${ }^{14}$ Ibidem.

15 Ibidem, p. 116. 
The Romantic era was a breakthrough period in the history of Western culture for several reasons. It was a time when the idea of authenticity was formulated and disseminated, the Western esoteric tradition was reinterpreted, and the cognitive primacy of the mind was questioned. Romanticism turned out to be a ground-shaking period in the history of the ecological movement; it was when Eco-enchantment took place - a process which accompanied Romantic re-enchantment as a reaction to creating the modern iron cage of effectiveness. Obviously, Romantics were not the first in their turn towards nature and criticism of the mechanistic model of the world. They were not the first to discover awareness in nature. However, due to the extensity of transformations and the advancement of the process of disenchantment with nature and alienation of humans (from nature), the Romantic response had to be effective enough to be a powerful influence on the modern, nineteenth century mentality which was being born.

Taking a stand against 1) the disenchanted concept of the world, 2) the goal of its quantification, 3) the mechanization of the world, 4) rationalist abstraction, and 5 ) the break-up of social bonds (criticism of egoism and individualism), ${ }^{16}$ Romantics rejected the model of modernity which separated people from their own interior, from one another and from the world of wildlife. ${ }^{17}$ The consecutive surges of neoRomanticization of the world were accompanied by an overcoming of this triple alienation - the concept of the living universe suggested by Duane Elgin fits into this current of criticism concerning the alienating power of modernity. Although fascination with the East is clearly seen in his works, ${ }^{18}$ it should be added immediately that, in his optimism, activist attitude and vision of sustainable social development, Elgin undoubtedly remains a child of the West. The voluntary simplicity movement, of which he is the well-recognizable face, stems from the Romantic heritage, especially from the works of American transcendentalists. ${ }^{19}$

Whether in the United States or in Europe, the novum introduced by Romanticism was the reinterpretation and popularization of the tradition of Western esoteric thought. Contact with the esoteric tradition occurred in the case of many members of the emerging artistic bohème, mostly such great poets as William Blake or Ralph Waldo Emerson, ${ }^{20}$ and - in Poland - Adam Mickiewicz, Juliusz Słowacki or Zygmunt Krasiński. The esoteric tradition also diffused into the works of philosophers associated with Romantic ideology (in particular, the closely linked German

${ }^{16}$ R. Sayre, M. Löwy, Romanticism and Capitalism [in:] A Companion to European Romanticism, M. Ferber (ed.), Oxford 2005, pp. 436-439.

${ }^{17}$ C. Taylor, Etyka autentyczności, op. cit., p. 76.

${ }^{18}$ Elgin himself admits practicing meditation and Zen Buddhism.

${ }^{19}$ David E. Shi in his book dedicated to the history of the idea of simplicity in the United States draws attention to its reinterpretation in the times of Romanticism. Until Romanticism, this idea had its justification in classical philosophy and the Protestant tradition. Treating nature as a source of aesthetic pleasure, morality and spiritual inspiration, Romantics not only reinterpreted nature itself, but also gave a new sense to simplicity itself (D.E. Shi, The Simple Life: Plain Living and High Thinking in American Culture, New York-Oxford 1985, p. 127).

${ }^{20}$ For the issues of vitality and life in the works of another Romantic poet, Percy Shelley, see: S. Ruston, Shelley and Vitality, London-New York 2005. 
Idealism - especially Friedrich Wilhelm Schelling's body of work - and the aforementioned American transcendentalism). Before presenting the characteristics of Elgin's concept of the living universe, my aim is to emphasize this esoteric aspect of the Romantic universum. Wouter J. Hanegraaff, in his study in which he explores the relations between Romanticism and the esoteric tradition, recognizes three categories as central to Romanticism: 1) organicism, 2) imagination, and 3) temporalism. ${ }^{21}$ These categories, as Hanegraaff notes, should at the same time be considered crucial for the esoteric tradition. ${ }^{22}$ Arthur O. Lovejoy in his text written in 1941, The Meaning of Romanticism for the Historian of Ideas, distinguished three criteria of Romanticism: organicism (holism), dynamism and differentiation. ${ }^{23}$ As Hanegraaff notes, Lovejoy's characterization of Romanticism can be de facto narrowed down to two ideas: diversified holism and Romantic evolutionism. ${ }^{24}$ René Wellek, on the other hand, recognized three ideas (imagination, nature, and symbols and myths) as the characteristic features of (English, French and German) Romanticism. ${ }^{25}$ In 1951, Morse Peckham made an attempt to reconcile the standpoints of Lovejoy and Wellek. He wrote that what is common to both authors is the same metaphor-dynamic organicism. ${ }^{26}$ Peckham noted that, regardless of whether philosophy, theology or aesthetics was being dealt with, Romanticism drifted away from mechanistic statics in the spirit of Newton in favour of thinking in terms of dynamic organicism, in which change, growth, diversity, creative imagination, and unconsciousness gained more significance. ${ }^{27}$

Even though each of the aspects of Romanticism distinguished by Hanegraaff is present in Elgin's works as well, the organicistic motif will be particularly focused on in this article. As mentioned earlier, Elgin's scientific oeuvre will be treated here as an exemplification of certain sociocultural processes which might be described by the umbrella term 'neo-Romanticization.'

Duane Elgin's most famous book is still Voluntary Simplicity, which was published for the first time in 1981. In it, he reiterates the major values (formulated in 1978 in his article written with Arnold Mitchell) constituting the foundation for the idea of voluntary simplicity: 1) material simplicity, 2) human scale (this is a reference to the famous expression small is beautiful, coined by Ernst F. Schumacher),

${ }_{21}$ W.J. Hanegraaff, Romanticism and the Esoteric Connection [in:] Gnosis and Hermeticism from Antiquity to Modern Times, R. van den Broek, W.J. Hanegraaff (eds.), Albany, NY 1998, p. 256.

${ }^{22}$ Hanegraaff addresses three theses presented by Antoine Faivre. Apart from the three already mentioned categories, Faivre characterizes esotericism through the ideas of correspondence, eternal philosophy and transmission of knowledge (A. Faivre, Renaissance Hermeticism and the Concept of Western Esotericism [in:] Gnosis and Hermeticism..., op. cit., pp. 119-120; see also: A. Faivre, Theosophy, Imagination, Tradition: Studies in Western Esotericism, Albany, NY 2000, pp. XXI-XXIV).

${ }^{23}$ A.O. Lovejoy, The Meaning of Romanticism for the Historian of Ideas, "Journal of the History of Ideas" 1941, vol. II, no. 3, p. 272.

${ }^{24}$ W.J. Hanegraaff, Romanticism and the Esoteric Connection, op. cit., p. 242.

${ }^{25}$ R. Wellek, The Concept of Romanticism in Literary History [in:] Romanticism: Points of View, R.F. Gleckner, G.E. Enscoe (eds.), Detroit-Michigan 1974, p. 193.

${ }^{26}$ M. Peckham, Toward a Theory of Romanticism [in:] Romanticism: Points of View, op. cit., p. 238.

27 Ibidem, p. 241. 
3) self-constitution, 4) ecological awareness, and 5) personal development. ${ }^{28}$ In Changing Images of Man, a work published in 1982 under the auspices of the Stanford Research Institute (SRI), Elgin presents an ideology based on the contestation of the mechanistic vision of the world and on a defence of the notion of life. ${ }^{29}$ In The Living Universe, published in 2010, he makes the ideas of voluntary simplicity a part of the concept of the living universe by glorifying organicism. In his works, especially in The Living Universe, Elgin builds the concept of the living universe, permeated with awareness and spirituality. It is significant that his deliberations start with a foreword by Deepak Chopra, recognized as one of the leading figures of the New Age. ${ }^{30}$ Elgin supports aiming at what is not material with the help of the ontological concept of the living universe. He also puts the choice between consumerism and voluntary simplicity in the context of the debate about the concept of the dead versus the living universe. While materialism, along with collecting things and drawing pleasure from possessing, seems a rational answer to the belief in the existence of a dead universe, the perspective of life in a living universe opens the door to the minimization of material things, and multiplying non-material riches: relations with people, care for the community, and creative expression. ${ }^{31}$ Elgin criticizes contemporary individualism - understood in terms of egoism and associated with breaking social bonds or the atomization of social life - by building a concept of a society based on cooperation and mutual liking. Therefore, a consequence of the belief in the existence of the living universe would be care not only for one's own but also others' wellbeing. ${ }^{32}$ It is here that praise of kindness and compassion is rooted. Thus, the aforementioned Romantic criticism of the triple alienation of contemporary people, living in the iron cage of effectiveness, obtains legitimization in the concept of the living universe.

Deepak Chopra observes a holistic perspective in Elgin's The Living Universe in which people are an integral part of a living and intelligent universe. ${ }^{33}$ Such a holistic perspective seems to be a lasting element of contemporary pop-occulture. Drawing on Campbell's category of Easternization, it can certainly be claimed that this is an effect of a clash of two different traditions which find their justification in religiousspiritual systems. Arguing with supporters of the mechanistic model of the universe, from which the so-called irrational experience has been eliminated, Elgin himself refers to the model of the human as the Master, the being who controls nature. ${ }^{34}$ This

${ }^{28}$ D. Elgin, A. Mitchell, Introduction. Voluntary Simplicity: A Movement Emerges [in:] Voluntary Simplicity: Responding to Consumer Culture, D. Doherty, A. Etzioni (eds.), Oxford 2003, pp. 147-152.

${ }^{29}$ See: Changing Images of Man, O.W. Markley, W. Harman (eds.), Oxford-New York-TorontoSydney-Paris-Frankfurt 1982, pp. 45-64. Although Changing Images of Man was prepared by a research team, Elgin is the main author of two chapters: Economic Man: Servant to Industrial Metaphors and Societal Choices and Consequences of Changing Images. It is worth mentioning that Joseph Campbell was also a member of the team.

${ }^{30}$ M. Introvigne, After the New Age: Is There a Next Age? [in:] New Age Religion and Globalization, M. Rothstein (ed.), Aarhus 2001, p. 64.

${ }^{31}$ D. Elgin, The Living Universe: Where Are We? Who Are We? Where Are We Going?, San Francisco 2009, pp. 13-14.

32 Ibidem, p. 14.

${ }_{33}^{3}$ D. Chopra, Foreword [in:] D. Elgin, The Living Universe..., op. cit., pp. IX-X.

${ }^{34}$ Changing Images of Man, op. cit., p. 47. 
image of humanity has its source, as Elgin claims, in the Judeo-Christian tradition, ${ }^{35}$ and Christianity itself is recognized as the most anthropocentric religion of the world, which legitimizes the dualism of nature and humanity. The neo-Romanticization, eco-enchantment or Orientalization of the West are concepts which undoubtedly share one feature: drawing attention to the weakening of the dualism of humanity and nature. The process of such a reinterpretation at the level of pop culture and occulture seems to be perfectly aptly illustrated by James Cameron's film Avatar. ${ }^{36}$ The film can be treated as a model occultural product, in which a suggestion appears of a holistic understanding of the relation humanity - nature (or more broadly: universe), as well as of the relation humanity - other creatures (conscious beings). Avatar as a part of the ecological debate on the instrumental attitude of humanity to the world, polemicizing with - as Elgin would say - Christian anthropocentrism, can also be treated as an echo of criticisms of the materialist attitude, in which "possessing has become a value." As Elgin wrote in his study, in which he presented an economic image of humanity, no civilization other than the Western one (permeated with the Prometheic myth) has put the emphasis on what might be instead of what is. No other civilization, as he added, has subordinated the world to its own will to a comparable extent. ${ }^{37}$ The plot of Avatar, based on the confrontation of two worlds - a human one, represented by greed, and a world in which the representatives of the $\mathrm{Na}$ 'vi race live, a world full of respect for life - introduces the viewer to the essence of a philosophical dispute that has sociocultural, economic or simply existential consequences for human life. Greed, written into the economic model of humanity, alienating contemporary people from themselves, others and nature, is compliant with the vision of the dead universe.

Deepak Chopra in his Foreword to Elgin's book draws attention to another characteristic feature of this author's works. As Chopra writes, Elgin adopts two attitudes at the same time - that of a researcher into scientific knowledge and into spiritual understanding. ${ }^{38}$ An attempt to integrate these two perspectives has been seen in Elgin's works right from the beginning: he started his research activities in the SRI think tank, where he worked on studies concerning the future and made some prognoses on sustainable social development. What can be seen here is an "unorthodox" approach to science, according to which the assertions that atoms have no awareness and that love and happiness are chemical processes ${ }^{39}$ do not need to be the final conclusions of modern science. Elgin writes that the awareness that humanity is a part of the living universe belongs to the wisdom-based tradition, for centuries promoted by people living in different places worldwide. Western thought constitutes an integral part of "the world's wisdom" as well. ${ }^{40}$ The Western tradition of thinking about the

${ }^{35}$ It is not the aim of this study to judge how justified such an unambiguous standpoint on the part of Elgin is.

${ }^{36}$ It is my student Jakub Mike who deserves my gratitude for drawing attention to the ecological dimension of the film Avatar.

${ }^{37}$ Changing Images of Man, op. cit., p. 48.

${ }^{38}$ D. Chopra, op. cit., p. IX.

39 D. Elgin, The Living Universe..., op. cit., p. 9.

${ }^{40}$ What seems an interesting motif employed by Elgin is the ecology of light - by (superficially) reconstructing the semantics of light in the culture of the West and the East, he draws attention to the 
living universe encompasses views presented by thinkers such as Heraclitus, Plotinus, Giordano Bruno, Schelling, Hegel and Bergson. Only recent centuries, which have highlighted the elevated position of humanity, have changed the concept itself of the universe, by dressing it in scientific robes. As Elgin claims, what we seem to be witnessing is a change in the paradigm of practising science, a change which allows for noticing the purposefulness and mystical character of nature. The definition of life and awareness changes as well. He writes that a certain level of awareness is indispensable in life and that primary perception is to become the foundation of the universe. A certain level of awareness can already be noticed at the level of atoms, bacteria, plants or animals - however, this is a different sort of awareness to that understood in relation to humans. Elgin's concept is similar - on the one hand - to the science of perception from Leibniz's Monadology, and - on the other - to Pierre Teilhard de Chardin's concept of the noosphere. In the same way that a monad reflects the whole world, everyone is connected to the universe..$^{41}$ By being connected to the whole universe, human awareness has the ability to reach far beyond the physical senses. ${ }^{42}$ Until recently, as Elgin writes, people thought they were only physical beings; today they are receiving a growing amount of information that they are cosmic creatures, who are a part of the unceasing process of reproducing the universe. ${ }^{43}$

Elgin's concept of the living universe is based on the idea of evolution. Evolutionism is an old esoteric belief, which can be found in orphic beliefs in the form of the myth of the fall. This myth appears in gnosticism, neo-platonism, and Kabbalah what is common to all these intellectual-religious traditions is the belief in the imperfection and incompleteness of humanity. Man, originally belonging to God's reality, falls (into sin, materiality). But esoteric knowledge (gnosis as true knowledge) which gives a true understanding of the history of creation and human nature - will allow humanity to come back to its original divine state. ${ }^{44}$ The Romantic concept of evolution, esoterically rooted but based on temporalization (the idea of placing something in time), had its foundation in the myth of the fall and rebirth. This was different from the scheme of Plotinus or the gnostics, where growing differentiation was not identified as evil, and what would come (unity and harmony) was associated with the belief that this target state would be more perfect than the initial state of the evolution process. This optimistic concept of evolution, based on the idea of progress, can be found in Elgin's works. As he notes, it is not aimed at progressing from materiality to awareness but at their integration. ${ }^{45}$ The evolutionary model is incorporated by Elgin into James Campbell's imagery of voyage (as Elgin himself writes, the archetype of human voyage is present here), consisting of a stage of separation and return home.

meaning of the terms Enlightenment, invisible and trans-visible. He mentions the figure of Gregory Palamas, who emphasizes the affinity of light and gnosis.

${ }^{41}$ The idea of correspondence, which Faivre includes in esoteric ideas, is dealt with here.

42 D. Elgin, The Living Universe..., op. cit., p. 51.

${ }^{43}$ Ibidem, p. 93.

${ }^{44}$ J. Iwersen, The Epistemological Foundations of Esoteric Thought and Practice, "Journal of Alternative Spiritualities and New Age Studies" 2007, vol. 3, p. 14.

${ }^{45}$ D. Elgin, The Living Universe..., op. cit., p. 126. 
Being a specific cultural invariant, the experience of such a voyage becomes a process of inner discovery and transformation, ${ }^{46}$ during which the hero undergoes an initiation and experiences awakening. The biggest challenge which the hero faces is killing the ego dragon, which will allow the hero to discover communion with the living universe. ${ }^{47}$

Elgin makes an attempt to apply the imagery of the human voyage to the history of Western societies, interpreting the industrial revolution in terms of separation from the living universe, from other people and from spiritual life. ${ }^{48}$ What seems important in his understanding of evolution is that the industrial revolution and its negative consequences are not some aberrations on the path of the evolution of awareness, but are an inseparable component - without separation, there would be no return and no awakening. As Elgin writes, humanity is half way to returning home, more mature, in the process of undergoing the crucial final test (Supreme Test). The range and depth of transformations force people to go beyond the individual awakening and to start thinking in terms of collective awakening. ${ }^{49}$ The upcoming new era will be a time of worldwide reconciliation between people in various dimensions (sex, race, nationality and religion), as well as of the reconciliation of humanity with nature. The approaching era will be a time of integration of opposites, of unity and multitude, of femininity and masculinity ${ }^{50}$ of wealth and poverty, or of what is transcendental and immanent. ${ }^{51}$

Planetary transformation is based on the concept of collective awareness (Elgin also writes about collective imagination). Discussion of collective awareness was particularly vibrant in sociology at the turn of the nineteenth and twentieth century and was mostly associated with Émile Durkheim. ${ }^{52}$ However, when dealing with the subject of collective awareness, Elgin refers to other traditions and bases it on Jung's concept of the collective unconscious ${ }^{53}$ Pierre Teilhard de Chardin's evolutionist approach to collective consciousness, and Ken Wilber's concept of awareness. Moreover, Elgin tries to anchor the concept of collective awareness in scientific discoveries, clearly emphasizing that in traditional science (he uses this exact expression) the idea of collective awareness is not possible. ${ }^{54}$ As he writes, a hundred years ago science

46 Ibidem, p. 132.

47 Ibidem, p. 133.

48 Ibidem, p. 138. In his interpretation of the industrial revolution, Elgin remains thoroughly Romantic, and the fields of separation distinguished by him overlap with areas of alienation, the existence of which was indicated by the Romantics.

49 In many points, the future epoch heralded by Elgin is similar to Marilyn Ferguson's The Aquarian Conspiracy (see: M. Ferguson, The Aquarian Conspiracy: Personal and Social Transformation in Our Time, New York 2009, p. 86).

50 Elgin highlights the significance of the female element in a special way, by writing: "We are She." He also uses the expression The Mother Universe.

51 D. Elgin, The Living Universe..., op. cit., p. 143.

${ }^{52}$ For more on the concept of Durkheim's collective awareness, see: A. Kasperek, Świadomość zbiorowa [in:] Formy świadomości społecznej, K. Sztalt, M. Zemło (eds.), Lublin 2014, pp. 45-67.

53 As regards Jung's works, Elgin often applies the notion of archetype.

${ }^{54}$ I think that in his argumentation, Elgin limits his scientific deliberations to the natural sciences, although he does not state this anywhere in the text. What he deals with is the way of practising science in 
offered a static model of the universe, whilst today it is discovering the world's mysterium and its dynamism, noticing the whole of it, of which humanity is only a part..$^{55}$ In Elgin's interpretation of collective awareness, this phenomenon is not solely limited to people and it constitutes a kind of "cloth which unites the cosmos," ${ }^{56}$ which clearly distinguishes Elgin from sociological approaches to this issue. Collective awareness evolves by going through consecutive stages which lead to the reaching of maturity by civilization..$^{57}$ As Elgin notes, this model of the evolution of collective awareness is consistent with the stages of human development distinguished by Western psychology, on the one hand, and with Eastern meditation traditions, on the other. ${ }^{58}$ The inspiration drawn from the Eastern meditation tradition is clearly seen when Elgin de facto equates collective awareness with mindfulness. ${ }^{59}$ This approach to development, ${ }^{60}$ obviously inspired by Zen Buddhism, occurs along with emphasis on the significance for civilizational advancement of such qualities as empathy, kindness, compassion, and hope ${ }^{61}$ In his works, Elgin broadens the Buddhist concept of enlightenment factors and applies them in relation to society. A self-aware, reflective society should have the following qualities: 1) self-constitution, 2) recognition of its own mistakes, 3) non-attachment, 4) inclusiveness, 5) anticipation, and 6) creativity. ${ }^{62}$

What, in my opinion, might summarize Elgin's concept of the living universe in the best way is a brief presentation of his description of the emergence of the new paradigm - though not the paradigm relating to science as understood by Kuhn. For Elgin, moving towards the new paradigm means achieving - by collective awareness - the next developmental stage, resulting in civilizational transformations, in which science is just a part of the broad range of changes involved. The direction of

which awareness (consciousness) is interpreted from the reductionist and mechanistic perspective (D. Elgin, C. LeDrew, Global Consciousness Change: Indicators of an Emerging Paradigm, San Anselmo 1997, p. 5).

55 D. Elgin, Collective Consciousness and Cultural Healing, San Anselmo 1997, p. 7.

56 Ibidem. Such an approach seems to be closest to Teilhard de Chardin's concept of the noosphere.

${ }^{57}$ Elgin distinguishes two phases in the evolution of awareness (consciousness), each phase consisting of three stages. The first phase, which is the domain of the collective unconscious, comprises: the hunter-gatherer era (collective awareness focused on senses), the agrarian era (collective awareness focused on feelings) and the industrial era (collective awareness focused on thinking). The second phase, which is the domain of collective awareness, comprises: the communication era (reflective awareness), the era of restoration ("oceanic" collective awareness), and of surpassing, where collective awareness becomes an awareness of flow) (ibidem, p. 12). See also: D. Elgin, Awakening Earth: Exploring the Evolution of Human Culture and Consciousness, New York 1993.

${ }^{58}$ Elgin particularly emphasizes that he is inspired by the works of the following authors: Mihaly Csikszentmilhalyi, Ken Wilber, Jean Gebser, Abraham Maslow (D. Elgin, Collective Consciousness and Cultural Healing, op. cit., p. 11).

${ }^{59}$ Ibidem, p. 12. Reflection on mindfulness plays a crucially important role in the environment of voluntary simplicity (see: M.A. Burch, Mindfulness: The Doorway to Simple Living, New York 2012, p. 2).

${ }^{60}$ See: T. Nhat Hanh, Cud uważności. Zen w sztuce codziennego życia: prosty podręcznik medytacji, trans. G. Draheim, Warszawa 1992.

${ }^{61}$ These features also make up what Dalai Lama calls "elementary spirituality" (Dalai Lama, H.C. Cutler, The Art of Happiness: A Handbook For Living, London 1998, p. 258).

${ }^{62}$ D. Elgin, Collective Consciousness and Cultural Healing, op. cit., p. 19. 
Elgin's suggestion is moving along an axis from the industrial/materialist paradigm to the reflective/living-systems paradigm. The following table is an illustration of the differences between these paradigms:

\begin{tabular}{|l|l|}
\hline \multicolumn{1}{|c|}{ Industrial/materialistic paradigm } & \multicolumn{1}{c|}{ Reflective/living-systems paradigm } \\
\hline $\begin{array}{l}\text { The cosmos is made up of mostly dead matter } \\
\text { and empty space and is not "alive." }\end{array}$ & $\begin{array}{l}\text { Our cosmos is a unique kind of "living orga- } \\
\text { nism" and, as a whole system, is fundamen- } \\
\text { tally alive. }\end{array}$ \\
\hline $\begin{array}{l}\text { We are floating through vast reaches of empty } \\
\text { space, and most of life seems to lack any lar- } \\
\text { ger sense of meaning and purpose. }\end{array}$ & $\begin{array}{l}\text { The entire cosmos is a unified system. Each } \\
\text { action is woven into the deeper ecology of the } \\
\text { universe. Everything we do matters. }\end{array}$ \\
\hline $\begin{array}{l}\text { Consciousness - when viewed from a re- } \\
\text { ductionistic, mechanistic perspective - is } \\
\text { a by-product of biochemistry and is located in } \\
\text { the brain. }\end{array}$ & $\begin{array}{l}\text { Consciousness - when viewed from an in- } \\
\text { tegrative, living-systems perspective - is an } \\
\text { ordinary capacity that permeates the universe } \\
\text { and provides a reflective capability appropria- } \\
\text { te to each entity within the universe. }\end{array}$ \\
\hline $\begin{array}{l}\text { The goal in life is material success and social } \\
\text { achievement. }\end{array}$ & $\begin{array}{l}\text { The goal in life is to develop a balanced rela- } \\
\text { tionship between our inner and outer lives - to } \\
\text { live in a way that is sustainable and compas- } \\
\text { sionate. }\end{array}$ \\
\hline $\begin{array}{l}\text { The emphasis is on conspicuous consumption. } \\
\text { The "good life" depends on having enough } \\
\text { money to buy access to pleasure and avoid } \\
\text { discomforts. }\end{array}$ & $\begin{array}{l}\text { The emphasis is on conscious consumption. } \\
\text { The "good life" is an ever-changing balance of } \\
\text { inner and outer, material and spiritual, perso- } \\
\text { nal and social, etc. }\end{array}$ \\
\hline $\begin{array}{l}\text { Identity is largely defined by material posses- } \\
\text { sions and social position [...]. }\end{array}$ & $\begin{array}{l}\text { Our sense of self grows through our conscio- } \\
\text { us, loving, and creative participation in life } \\
\text { [..] }\end{array}$ \\
\hline $\begin{array}{l}\text { It is natural that we who are living use lifeless } \\
\text { material resources for our own progress. }\end{array}$ & $\begin{array}{l}\text { The individual is both unique and an insepa- } \\
\text { rable part of the larger universe. Our being is } \\
\text { not limited to our physical existence. }\end{array}$ \\
\hline $\begin{array}{l}\text { Cutthroat competition is the norm. You com- } \\
\text { pete against others to make a killing [...]. }\end{array}$ & $\begin{array}{l}\text { Fair competition is the norm. You cooperate } \\
\text { with others to earn a living [...]. }\end{array}$ \\
\hline
\end{tabular}

Source: D. Elgin, C. LeDrew, Global Consciousness Change: Indicators of an Emerging Paradigm, San Anselmo 1997, p. 5.

The reflective paradigm, as a set of imaginations concerning the universe, nature, society and humanity, is also a presentation of Elgin's imaginations pertaining to ways of practicing physics, biology, sociology and psychology (and other sciences not mentioned here). The concept of a living, dynamic universe, permeated with awareness, organizes this holistic paradigm, which is a good example of the earlier discussed process of the neo-Romanticization of the world. Eco-enchantment, promoted by Elgin since the beginning of his work, is the foundation and inspiration for this paradigm. In this study, I have only dealt with one, the organicistic spectrum 
of the neo-Romantic worldview, leaving other, no less significant, motifs - mostly imagination and temporalism - outside my research interests. Finally, I would like to stress that Elgin's works and activity, reflecting broader social processes, constitute a factor of social change, which reached its most mature manifestation in the voluntary simplicity movement. In his foreword to the new edition of Voluntary Simplicity issued in 2010 (first edition: 1981), Duane Elgin drew attention to how much, over the last three decades, interest has increased in the idea of a more sustainable and environmentally-friendly life - the idea promoted by protagonists of voluntary simplicity. This idea has migrated from the fringes to the cultural mainstream of contemporary society. ${ }^{63}$

\section{References}

Barkun M., A Culture of Conspiracy: Apocalyptic Visions in Contemporary America, Berkeley 2003.

Burch M.A., Mindfulness: The Doorway to Simple Living, New York 2012.

Campbell C., The Cult, the Cultic Milieu and Secularization, "A Sociological Yearbook of Religion in Britain" 1972, no. 5, pp. 119-136.

Campbell C., The Easternization of the West [in:] New Religious Movements: Challenge and Response, B. Wilson, J. Cresswell (eds.), London 1999, pp. 35-48.

Campbell C., The Easternization of the West: A Thematic Account of Cultural Change in the Modern Era, Boulder-London 2007.

Campbell C., The Easternization of the West: Reflections on a New Theodicy for a New Millennium [in:] The Ethics of the Future, E.R. Laretta (ed.), Geneva 1998, pp. 286-312.

Changing Images of Man, O.W. Markley, W.W. Harman (eds.), Oxford-New York-Toronto-Sydney-Paris-Frankfurt 1982.

Chopra D., Foreword [in:] D. Elgin, The Living Universe: Where Are We? Who Are We? Where Are We Going, San Francisco 2009, pp. ix-x.

Dalai Lama, Cutler H.C., The Art of Happiness: A Handbook For Living, London 1998.

Elgin D., Awakening Earth: Exploring the Evolution of Human Culture and Consciousness, New York 1993.

Elgin D., Collective Consciousness and Cultural Healing, San Anselmo 1997.

Elgin D., The Living Universe: Where Are We? Who Are We? Where Are We Going?, San Francisco 2009.

Elgin D., Voluntary Simplicity: Toward a Way of Life that is Outwardly Simple, Inwardly Rich, New York 2010.

Elgin D., LeDrew C., Global Consciousness Change: Indicators of an Emerging Paradigm, San Anselmo 1997.

Elgin D., Mitchell A., Introduction. Voluntary Simplicity: A Movement Emerges [in:] Voluntary Simplicity: Responding to Consumer Culture, D. Doherty, A. Etzioni (eds.), Oxford 2003, pp. 1-25.

Faivre A., Renaissance Hermeticism and the Concept of Western Esotericism [in:] Gnosis and Hermeticism from Antiquity to Modern Times, R. van den Broek, W.J. Hanegraaff (eds.), Albany, NY 1998, pp. 109-123.

Faivre A., Theosophy, Imagination, Tradition: Studies in Western Esotericism, Albany, NY 2000.

${ }^{63}$ D. Elgin, Voluntary Simplicity: Toward a Way of Life that is Outwardly Simple, Inwardly Rich, New York 2010, pp. XXV-XXVII. 
Ferguson M., The Aquarian Conspiracy: Personal and Social Transformation in Our Time, New York 2009.

Hanegraaff W.J., Romanticism and the Esoteric Connection [in:] Gnosis and Hermeticism from Antiquity to Modern Times, R. van den Broek, W.J. Hanegraaff (eds.), Albany, NY 1998, pp. 237 268.

Introvigne M., After the New Age: Is There a Next Age? [in:] New Age Religion and Globalization, M. Rothstein (ed.), Aarhus 2001, pp. 58-69.

Iwersen J., The Epistemological Foundations of Esoteric Thought and Practice, "Journal of Alternative Spiritualities and New Age Studies" 2007, vol. 3, pp. 3-44.

Kasperek A., Świadomość zbiorowa [in:] Formy świadomości społecznej, K. Sztalt, M. Zemło (eds.), Lublin 2014, pp. 45-67.

Kasperek A., Wolność spod znaku undergroundu. Duchowość (po)nowoczesna w perspektywie hermeneutyki kultury i socjologii religii, Kraków 2012.

Lovejoy A.O., The Meaning of Romanticism for the Historian of Ideas, "Journal of the History of Ideas" 1941, vol. II, no. 3, pp. 257-278.

Nhat Hanh T., Cud uważności. Zen w sztuce codziennego życia: prosty podręcznik medytacji, trans. G. Draheim, Warszawa 1992.

Partridge C., Occulture is Ordinary [in:] Contemporary Esotericism, E. Asprem, K. Granholm (eds.), Lancaster-Bristol 2013, pp. 113-133.

Partridge C., The Re-Enchantment of the West: Alternative Spiritualities, Sacralization, Popular Culture, and Occulture, London-New York 2004-2005, vol. 1-2.

Peckham M., Toward a Theory of Romanticism [in:] Romanticism: Points of View, R.F. Gleckner, G.E. Enscoe (eds.), Detroit-Michigan 1974, pp. 231-257.

Ruston S., Shelley and Vitality, London-New York 2005.

Sayre R., Löwy M., Romanticism and Capitalism [in:] A Companion to European Romanticism, M. Ferber (ed.), Oxford 2005, pp. 433-449.

Shi D.E., The Simple Life: Plain Living and High Thinking in American Culture, New York-Oxford 1985.

Taylor C., Etyka autentyczności, trans. A. Pawelec, Kraków-Warszawa 1996.

Taylor C., The Ethics of Authenticity, Cambridge, MA 1991.

Tiryakian E.A., Toward the Sociology of Esoteric Culture [in:] On the Margin of the Visible. Sociology, the Esoteric, and the Occult, E.A. Tiryakian (ed.), New York-London-Sydney-Toronto 1974, pp. 257-280.

Wellek R., The Concept of Romanticism in Literary History [in:] Romanticism: Points of View, R.F. Gleckner, G.E. Enscoe (eds.), Detroit-Michigan 1974, pp. 181-206. 